Accepted refereed manuscript of:

Sikor T, Auld G, Bebbington A, Benjaminsen T, Gentry B, Hunsberger $C$, Izac A, Margulis M, Plieninger T, Schroeder H \& Upton C (2013) Global Land Governance: From Territory to Flow?, Current Opinion in Environmental Sustainability, 5 (5), pp. 522-527.

DOI: $10.1016 / j$. cosust.2013.06.006

(C) 2015, Elsevier. Licensed under the Creative Commons AttributionNonCommercial-NoDerivatives 4.0 International

http://creativecommons.org/licenses/by-nc-nd/4.0/ 


\section{Global land governance: from territory to flow?}

Thomas Sikor (corresponding author), School of International Development, University of East Anglia, Norwich, NR4 7TJ, UK, t.sikor@uea.ac.uk, tel. +44-1603-593372, fax. +441603-451999

Graeme Auld, School of Public Policy and Administration, Carleton University, 5206 River Building, 1125 Colonel By Drive, Ottawa, ON K1S 5B6, Canada, Graeme_auld@carleton.ca

Anthony J. Bebbington, Graduate School of Geography, Clark University, 950 Main Street, Worcester, MA 01610, U.S.A., abebbington@clarku.edu

Tor A. Benjaminsen, Norwegian University of Life Sciences, P.O. Box 5003, 1432 Aas, Norway, torbe@umb.no

Bradford S. Gentry, Yale School of Forestry and Environmental Studies, Kroon Hall, 195 Prospect Street, New Haven, CT 06410, U.S.A., bradford.gentry@yale.edu

Carol Hunsberger, Institute of Social Studies, Kortenaerkade 12, 2518 AX The Hague, The Netherlands, hunsberger@iss.nl

Anne-Marie Izac, Consortium of the CGIAR, Agropolis International, Avenue Agropolis, 34394 Montpellier Cedex 5, France, a.izac@cgiar.org

Matias E. Margulis, Department of International Studies, University of Northern British Columbia, 3333 University Way, Admin 3011, Prince George, BC V2N 4Z9, Canada, margulis@unbc.ca

Tobias Plieninger, Berlin-Brandenburg Academy of Sciences and Humanities, Ecosystem Services Research Group, Jägerstr. 22/23, 10117 Berlin, Germany, plieninger@bbaw.de

Heike Schroeder, School of International Development, University of East Anglia, Norwich, NR4 7TJ, UK, h.schroeder@uea.ac.uk

Caroline Upton, Department of Geography, University of Leicester, Bennett Building, University Road, Leicester LE1 7RH, U.K., cu5@le.ac.uk

\section{$\underline{\text { Abstract }}$}

This article reviews recent research on contemporary transformations of global land governance. It shows how changes in global governance have facilitated and responded to radical revalorizations of land, together driving the intensified competition and struggles over land observed in many other contributions to this special issue. The rules in place to govern land use are shifting from "territorial" towards "flow-centered" arrangements, the latter referring to governance that targets particular flows of resources or goods, such as certification of agricultural or wood products. The intensifying competition over land coupled with shifts towards flow-centered governance has generated land uses involving new forms of social exclusion, inequity and ecological simplification.

Highlights 
- Global governance refers to rules at all levels having transnational repercussions.

- Changes in global governance have facilitated and responded to land revalorizations.

- Land governance is shifting from territorial towards flow-centered forms.

- The shift is generating new ecological simplifications and social injustices.

- Future land governance needs to combine flow-centered and territorial forms at multiple levels.

\section{$\underline{\text { Introduction }}$}

It might seem counterintuitive to speak of 'global land governance' when there is no globallevel organization with a comprehensive mandate to govern land? Even the United Nations Food and Agriculture Organization, by statute an international organization, resorted to the development of voluntary guidelines in contrast to obligatory rules for its member states when it recently issued guidance on the governance of land tenure [1].

Yet global governance is not the domain of supra-national organizations alone. It involves multiple actors - governments, businesses, NGOs, social movements, and others - and goes beyond global-level rules alone. Global governance can therefore be better understood as "systems of rule at all levels of human activity - from the family to the international organization - in which the pursuit of goals through the exercise of control has transnational repercussions” [2].

This article reviews recent research on contemporary transformations of global land governance, as understood this way. We organize the review around three interrelated propositions (see also Figure 1). First, changes in global governance have facilitated and responded to radical revalorizations of land, together driving the intensified competition and struggles over land observed in many other contributions to this special issue. Second, the rules in place to govern land use are shifting from "territorial" towards "flow-centered" arrangements, the latter referring to governance targeting particular flows of resources or goods, such as certification of agricultural or wood products. Third, the intensifying competition over land coupled with shifts towards flow-centered governance has generated land uses involving new forms of social exclusion, inequity and ecological simplification.

Figure 1: Contemporary transformations of global land governance

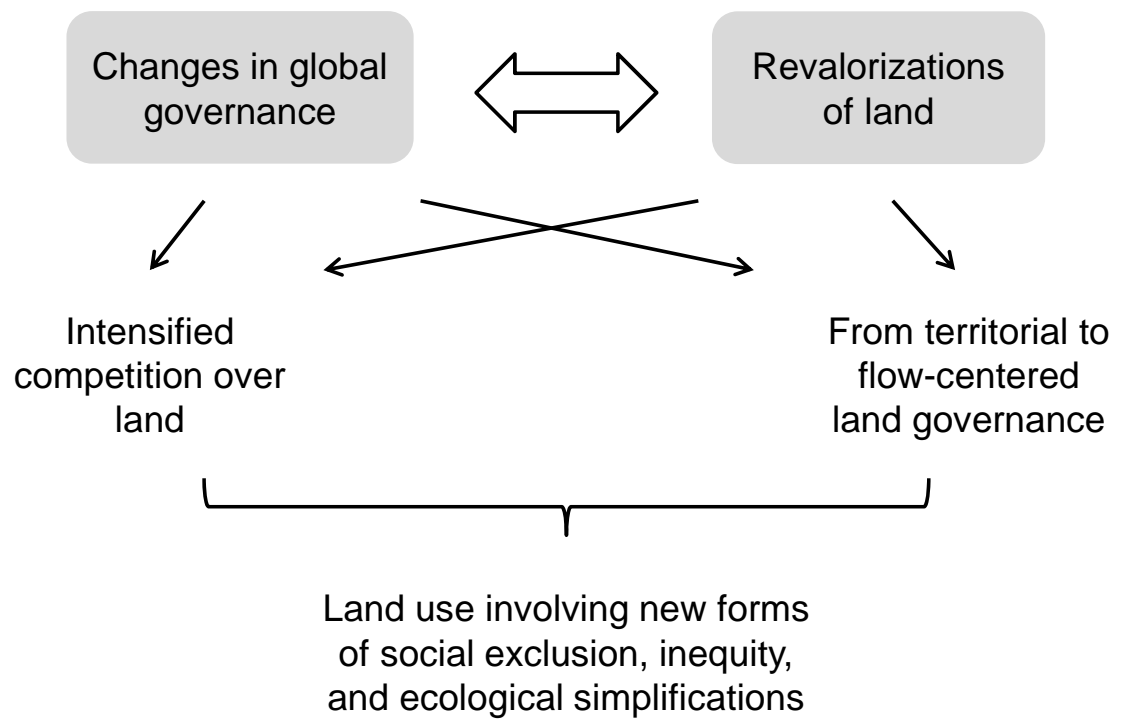




\section{$\underline{\text { Revalorizations }}$}

Revalorization is the process through which qualitatively or quantitatively distinct values, which differ from those previously extant or recognized, are given to specific lands. These values might be monetary - as with the creation of new commodities or shifting terms of trade - or political and cultural - as when new meaning and significance is given to land.

Changes in global agricultural production constitute one of the most visible revalorizations of land over the past decade in an economic (land being a necessary productive asset), political (land being a signifier of national food security) and cultural sense (land being perceived in close connection with agriculture). Concerns over food security have caused large-scale land acquisitions by states, transnational corporations and financial investors [3,4]. The land acquisitions have been enabled by the development of a market-driven international agricultural trade under the World Trade Organization (WTO), national policies on food, agriculture and trade among governments in the Global North and South, and the emergence of global commercial land markets and other mechanisms granting or preventing outside investors access to agricultural land [5-9]. Likewise, demand for alternative sources of energy has driven land acquisitions for the purpose of biofuel production [10]. In addition, agriculture is now often conceived as indispensable in the provision of a set of cultural, environmental and social services from land [11]. For example, European Union and national policies have supported agriculture for the preservation of diverse or traditional landscapes in ways compatible with WTO rules [12].

Something very similar has occurred in global mineral and hydrocarbon value chains. Demand for these resources has increased as a result of: economic growth in emerging economies leading to demand for materials for buildings and consumer goods; global economic volatility driving demand for investments (such as gold) seen as more secure than currencies; and technological change that has given increased value to some deposits (e.g. shale based hydrocarbons) [13-15]. Diverse governance mechanisms have facilitated the extension of natural resource extraction. These mechanisms range from the international to the local and include: stock markets enabling resource companies' access to investment capital; national policy reforms facilitating extractive industry acquisition of land and subsurface rights; corporate social responsibility instruments designed to secure "social license to operate;" and fiscal reforms designed to secure local interest in resource extraction [16-19].

Forests have undergone radical revalorizations over the past decade away from a sole focus on wood supply towards attention to their function in global carbon and regional water dynamics. Carbon forestry has developed steadily through thousands of small-scale reforestation and forest protection projects in the so-called voluntary sector, in which Northern buyers and Southern producers transact in a decentralized manner [20]. Forest carbon became a major topic for global negotiators only recently, when they initiated actions on Reducing Emissions from Deforestation and Forest Degradation (REDD+) [21,22]. Yet even then, emergent global-level rules on REDD+ show direct influences from civil society actors outside the main negotiation room [23] as well as experience from the hundreds of demonstration projects implemented worldwide, although protests against aspects of REDD+ continue $[24,25]$. 
The emergence of REDD+ has been strongly influenced by the assertion of political and cultural values tied to land by indigenous peoples' mobilizations at local, national and transnational levels. The mobilizations have highlighted the value of land as a place of belonging, as sacred territories and/or for the exercise of political self-determination, promoting explicit recognition of a diverse array of pre-existing values within contemporary struggles over land [26]. The mobilizations have driven this ongoing process of revalorization by targeting global-level governance and international law, such the UN Declaration on the Rights of Indigenous Peoples and the principle of Free, Prior and Informed Consent [27] and strategies of international conservation organizations [28], yet also influenced national and sub-national legislation [29,30] and local-level practices, such as revenue-sharing around protected areas [31].

This brief overview is far from exhaustive. Nonetheless, it stresses how changes in governance interact with global revalorizations of land to drive land use change. It also shows that the underlying changes of governance occur at global, national and local levels. Taken together these changes assumed a global dimension, contributing to the intensified competition over land [32].

\section{From territory to flow}

A second and connected trend observed in recent research is that land governance, i.e. the rules purposively put in place to facilitate socially desirable forms of land use, has gradually moved from territorial to flow-centered arrangements. Flow-centered arrangements are nothing new to governance if one considers, among others, colonial trading companies and monopolies. Yet, there is a discernible trend in land governance away from the classic territorial forms that had become dominant with the rise of the modern nation state, such as land use regulations made by central governments, land use planning conducted by local governments, and land management undertaken by local communities. New forms of land governance have emerged centered on particular flows of resources and goods. ${ }^{1}$ These forms, such as production standards in agricultural value chains, voluntary regulation in the mining sector, and forest certification, have been consciously brought into being by a range of stakeholders and coalitions, some seeking to overcome the perceived restrictions of territorially based governance, others seeking to install new forms of oversight [34].

Classic territorial arrangements continue to assume a significant role in contemporary land governance. For example, governments continue to establish protected areas for the conservation of biodiversity [35], initiate land reforms [36], and conduct land consolidation programs [37]. International conservation organizations promote Indigenous and Community Conserved Areas (ICCAs) [28]. Rural residents employ zoning ordinances to preserve desirable landscape features [11].

In addition, territorial governance makes use of new instruments, in particular novel financial mechanisms such as taxes, subsidies and payments [38]. The experience with Payments for Ecosystem Services (PES) is particularly insightful in this regard. Originally conceived as a voluntary, market-based transaction [39], PES has long evolved beyond the envisioned dual relationship between willing buyers and willing sellers [40]. Research now recognizes that PES typically requires the involvement of states for their territorial powers, whether it takes

\footnotetext{
${ }^{1}$ These new forms of governance have also been called private regulations on the basis of the central involvement of non-governmental actors, yet this terms is problematic considering that private actors act publicly when they develop such regulations [33].
} 
the form of large-scale programs such as China's Sloping Land Conversion Program [41] or small-scale projects [42].

Nonetheless, we contend that these reinventions of territorial governance are paralleled and even eclipsed by the ascendance of flow-centered arrangements. In agriculture, concentration in global commodity chains has facilitated industry-led efforts to introduce new forms of governance, such as production and sustainability standards [43,44]. Other examples come from NGO and multi-stakeholder certification schemes for organic, fair, local, slow, etc. food operating at global or regional levels, which have typically preceded similar efforts by national governments $[45,46]$. Concentration in the minerals and hydrocarbon sector has likewise aided industry led and multi-stakeholder efforts to create new governance instruments. For instance, the International Council on Mining and Metals, established in 2001 and bringing together 22 of the world's largest companies and 34 mining associations, produces voluntary guidelines for its members' operations, many of which affect company level codes of Corporate Responsibility (see http:// www.iccmm.com/).

Land governance on tropical forests is currently at an important crossroads. If the global REDD+ initiative develops into a global financing mechanism focused exclusively on the reduction of carbon emissions, much of future forest governance may broadly resemble the certification programs formed to promote responsible management of forests worldwide [47]. However, if REDD+ comes to embrace a sustainable forestry or landscape-based low emissions approach, classic territorial instruments such as tenure reforms and management planning may be more important, thereby re-centralizing control in the hands of central governments $[48,49]$.

Overall, there is a discernible shift in land governance from territorial towards flow-centered arrangements. This shift plays out in geographically uneven ways, extending from situations dominated by flow-centered arrangements such as in East Africa's cut flower industries [50] to places and countries with strong territorial governance such as in Vietnam [51].

\section{Effects on land use}

The dominance of governance arrangements centered on particular flows of resources has material effects on the provision of other resources or ecosystem services. For example, increases in agricultural prices or yields can cause deforestation [32,52]. The expansion of global food production or changes in European diets may raise global greenhouse gas emissions or cause other environmental effects [53,54]. Increases in carbon stocks facilitated by REDD+ can have detrimental effects on biodiversity, agricultural production, freshwater provision and traditional resource-based livelihoods, revalorizations and mobilizations by indigenous/ local peoples notwithstanding [55]. Similarly, the production of biofuel crops for the reduction of green house gas emissions in the energy sector can increase land use-related carbon emissions, reduce biodiversity or cause soil erosion [56,57].

The tendency of flow-based governance arrangements to privilege industrial interests can lead to the exclusion of smallholders in the Global South [58]. Exclusion may come about as an effect of unfavorable terms of trade within commodity and input markets [59], the predatory practices of state officials on land owners [60,61], or production standards [62,63]. However, much attention in research has focused on smallholders' straight dispossession from land, often captured under the term 'land grabbing' [4,64]. 
Similarly, the universalizing elements of flow-based governance can lead to the marginalization of ethnic minorities and other people outside the cultural mainstream. For example, research on the benefit-sharing agreements commonly employed by transnational mining companies shows that they can cause unintended cultural changes, such as the monetization of indigenous economies and individualization of property rights previously held in common [65]. Certification schemes have problems accommodating local forms of resources management even if they are designed to promote sustainable production [66].

These effects are related to more general features of flow-centered governance. Flowcentered governance tends to be dominated by powerful actors, such as Northern industry and transnational corporations and more recently new players from the Global South such as Brazil and China $[67,68]$. Moreover, flow based governance mechanisms related to trade and investment have been used to weaken or prevent efforts to institute territorially based land and environmental governance mechanisms on the grounds that they compromise investor rights or introduce trade advantages to particular resource users [69]. Thus, the shift towards flow-based governance has often been connected to intense political struggles, as illustrated by demands made around the 'right to food' at local, national and global levels. Increasing food prices resulted in 'food riots' [70] as well as civil society resistance to the promotion of biofuels under the theme 'food versus fuel' at local and national level [71]. The resistance has also caused efforts to institutionalize food as a human right at the international and national levels, as most visibly illustrated by the work of the UN Special Rapporteur on the Right to Food [72].

\section{Implications for research in land change science}

We conclude that recent insights on global land governance bear direct implications for research in land change science. Contemporary transformations of global governance are a significant cause, central dynamic and important effect of the intensifying competition over land observed in many contributions to this special issue. Wider changes in global governance both facilitate and are brought into being by the radical revalorizations of land underlying the competition. The shift from territorial to flow-centered rules governs land competition in ways that favor some land uses (and users) over others. The intensifying competition over land and shifts in governance affect land use in ways that introduce new injustices and ecological simplifications. Among others, one of the tasks land change scientists may tackle first is to analyze the geographical spread of the ongoing shift from territorial to flow-centered land governance and relate its spatial pattern to the distribution of changes in land use, struggles over land, and dispossession from land, which are already being mapped.

The insights synthesized here also possess direct relevance for land policy. They caution against the belief that the establishment of a global-level organization with a comprehensive mandate on land would lead to better land management worldwide. Future land governance will most likely need to combine territorial and flow-centered arrangements at multiple levels. The key challenges are to strengthen the democratic accountability of flow-centered arrangements, and to calibrate their synergies and complementarities with territorial governance better.

\section{$\underline{\text { Acknowledgements }}$}


The review originates from a working group on 'Decision-making, Governance, and Institutions at the Ernst Strüngmann Forum on Rethinking Global Land Use in an Urban Era, held in Frankfurt on September 23-28, 2012. The report of the working group is forthcoming [73]. Sikor acknowledges financial support from the I-REDD+ project funded by the European Union (Project No. 265286) for his writing time.

\section{$\underline{\text { References }}$}

1. Food and Agriculture Organization (FAO): Voluntary Guidelines on the Responsible Governance of Tenure of Land, Fisheries and Forests in the Context of National Food Security. Rome: Food and Agriculture Organization (FAO); 2012.

2. Rosenau JN: Governance in the Twenty-first Century. Global Governance 1995, 1:1343.

3. Cotula L: The international political economy of the global land rush: A critical appraisal of trends, scale, geography and drivers. The Journal of Peasant Studies 2012, 39:649-680.

4. White B, Borras Jr. SM, Hall R, Scoones I, Wolford W: The new enclosures: critical perspectives on corporate land deals. The Journal of Peasant Studies 2012, 39:619647.

**First major compilation of empirical studies on large-scale land acquisitions with a focus on their economic and political dymensions.

5. McMichael P: The land grab and corporate food regime restructuring. The Journal of Peasant Studies 2012, 39:681-701.

6. Margulis ME: Global food governance: The Committee for World Food Security, G8/G20 and the Comprehensive Framework for Action. In The Challenge of Food Security. Edited by Rayfuse R, Wiesfelt N: Edward Elgar.; 2012:231-254.

7. Margulis ME, Borras JS, McKeon. N: Land grabbing and global governance: A critical Introduction. Globalizations 2013, 10.

8. Eakin H, Winkels A, Sendzimir J: Nested Vulnerability: Exploring Cross-Scale Linkages and Vulnerability Teleconnections in Mexican and Vietnamese Coffee Systems. Environmental and Science Policy 2008:1-15.

9. Peluso N, Lund C: New frontiers of land control: Introduction. The Journal of Peasant Studies 2011, 38:667-681.

10. Anseeuw W, Boche M, Breu T, Giger M, Lay J, Messerli P, Nolte K: Transnational Land Deals for Agriculture in the Global South. Analytical Report based on the Land Matrix Database. Bern, Montpellier and Hamburg: CDE/CIRAD/GIGA; 2012.

11. Plieninger T, Ferranto S, Huntsinger L, Kelly M, Getz C: Appreciation, use, and management of biodiversity and ecosystem services in California's working landscapes. Environmental Management 2012, 50:427-440.

12. Plieninger T, Schleyer C, Schaich H, Ohnesorge B, Gerdes H, Hernandez-Morcillo M, Bieling C: Mainstreaming ecosystem services through reformed European agricultural policies. Conservation Letters 2012, 5:281-288.

13. Bebbington A, Bury J: Institutional challenges for mining and sustainability in Peru. Proceedings of the National Academy of Sciences of the United States of America 2009, 106:17296-17301.

14. Bridge G: Global production networks and the extractive sector: governing resourcebased development. Journal of Economic Geography 2008, 8:389-419.

15. Bridge G, Le Billon P: Oil. Cambridge: Polity Press; 2012.

16. Bebbington A (Ed): Social Conflict, Economic Development and Extractive Industry:

Evidence from South America London: Routledge; 2012. 
**Empirically-rich inquiry about the economic effects of and political responses to extractive industries in Latin America.

17. Collier P, Venables A: Plundered Nations? Successes and Failures in Natural Resource Extraction. New York: Palgrave MacMillan; 2011.

18. Sagebien J, Lindsay N-M (Ed): Governance Ecosystems: CSR in the Latin American Mining Sector London: Palgrave Macmillan; 2011.

19. Arellano-Yanguas J: Aggravating the resource curse: decentralisation, mining and conflict in Peru. Journal of Development Studies 2011, 47:617-638.

20. Bumpus AG, Liverman DM: Accumulation by Decarbonization and Governance of Carbon Offests. Economic Geography 2008, 84:127-155.

21. Corbera E, Schroeder H, Springate-Baginski O (Ed): Governing and Implementing $R E D D+$. Special issue of Environmental Science \& Policy 14(2); 2011.

**First major compilation on the emerging governance of REDD+.

22. Thompson MC, Baruah M, Carr ER: Seeing REDD+ as a project of environmental governance. Environmental Science \& Policy 2011, 14(2):100-110.

23. Schroeder $\mathrm{H}$ : Agency in international climate negotiations: the case of indigenous peoples and avoided deforestation. International Environment Agreements 2010, 10:317-332.

24. Angelsen A, Brockhaus M, Sunderlin WD, Verchot LV (Ed): Analyzing REDD+: Challenges and Choices Bogor, Indonesia: CIFOR; 2012.

25. Hiraldo R, Tanner T: Forest voices: competing narratives over REDD+. IDS Bulletin 2011, 42:42-51.

26. Scurrah M (Ed): Defendiendo Derechos y Promoviendo Cambiois: el Estado, las empresas extractivas y las comunidades locales en el Perú Lima: Instituto de Estudios Peruanos; 2006.

27. Lyster R: REDD+, transparency, participation and resource rights: the role of law. Environmental Science \& Policy 2011, 14:118-126.

28. Stevens S: Implementing the UN Declaration on the Rights of Indigenous Peoples and International Human Rights Law Through Recognition of ICCAs. Policy Matters 2010, 17:181-194.

29. Berkes F: Community conserved areas: policy issues in historic and contemporary context. Conservation Letters 2008, 2:19-24.

30. Tony F: Decentralization and REDD+ in Brazil. Forests 2011, 2:66-85.

31. Martin A, Akol A, Phillips J: Just conservation? On the fairness of sharing benefits. In The Justices and Injustices of Ecosystem Services. Edited by Sikor T: Earthscan; 2013.

32. Lambin EF, Meyfroidt P: Global land use change, economic globalization, and the looming land scarcity. Proceedings of the National Academy of Sciences of the United States of America 2011, 108:3465-3472.

*Insightful synthesis of research findings on competition between agriculture and forestry over land within globalizing context, and how national policy and governance mediates the competition.

33. Sikor T (Ed): Public and Private in Resource Governance: A False Dichotomy? London: Earthscan; 2008.

34. Auld G: Private market-based regulation: What they are, and what they mean for land-use governance. In Rethinking Global Land Use in an Urban Era. Edited by Seto K, Reenberg A: MIT Press; 2013.

35. Stahl J, Sikor T, Dorondel S: The Institutionalization of Property Rights in Albanian and Romanian Biodiversity Conservation. International Journal of Agricultural Resources, Governance and Ecology 2009, 8:57-73. 
36. Sikor T, Mueller D: The Limits of State-Led Land Reform. World Development 2009, 37:1307-1316.

37. Sikor T, Mueller D, Stahl J: Land fragmentation and cropland abandonment in Albania: Implications for the roles of state and community in postsocialist land consolidation. World Development 2009, 37:1411-1423.

38. Ring I: Biodiversity governance: Adjusting local costs and global benefits. In Public and Private in Natural Resource Governance: A False Dichotomy? Edited by Sikor T: Earthscan; 2008:107-126.

39. Wunder S: Payments for environmental services: Some nuts and bolts. In Occassional Paper No. 42. Center for International Forestry Research; 2005.

40. Muradian R, Corbera E, Pascual U, Kosoy N, May PH: Reconciling theory and practice: An alternative conceptual framework for understanding payments for environmental services. Ecological Economics 2010, 69:1202-1208.

**Article introduces innovative compilation of empirically-based and theoretically-informed analyses of PES that move beyond the assumptions underlying previous research.

41. Bennett M: China's sloping land conversion program: Institutional innovation or business as usual? Ecological Economics 2008, 65:699-711.

42. Wunder S, Engel S, Pagiola S: Taking stock: A comparative analysis of payments for environmental services programs in developed and developing countries. Ecological Economics 2008, 65:834-852.

43. Bailis R, Baka J: Constructing sustainable biofuels: governance of the emerging biofuel economy. Annals of the Association of American Geographers 2011, 101:827-838.

**Cutting-edge analysis of new modes of governance in which an array of non-nation-state actors (NNSAs) drive norms and behaviors related to the production and consumption of goods and services with potentially large environmental and social impacts.

44. Schouten G, Glasbergen P: Creating legitimacy in global private governance: The case of the Roundtable on Sustainable Palm Oil. Ecological Economics 2011, 70:1891-1899.

45. Overton J, Heitger J: Maps, markets and Merlot: the making of an antipodean wine appellation. Journal of Rural Studies 2008, 24:440-449.

46. Auld G: Assessing certification as governance: Effects and broader consequences for coffee. Journal of Environment and Development 2010, 19:215-241.

47. Auld G, Gulbrandsen LH, McDermott C: Certification schemes and the impact on forests and forestry. Annual Review of Environment and Resources 2008, 33:187211.

48. Phelps J, Webb EL, Agrawal A: Does REDD+ Threaten to Recentralize Forest Governance? Science 2010, 328:312-313.

49. Sandbrook C, Nelson F, Adams WM, Agrawal A: Carbon, forests and the REDD paradox. Oryx 2010, 44:330-334.

50. Riisgard L: Global value chains, labor organization and private social standards: Lessons from East African flower industries. World Development 2009, 37:326340.

51. Sikor T: Tree plantations, politics of possession and the absence of land grabs in Vietnam. The Journal of Peasant Studies 2012, 39:1077-1101.

52. DeFries RS, Rudel T, Uriarte M, Hansen M: Deforestation driven by urban population growth and agricultural trade in the twenty-first century. Nature Geoscience 2010, 3:178-181. 
53. Tukker A, Goldblohm RA, de Koning A, Verheijden M, Kleijn R, Wolf O, PerezDomienguez I, Rueda-Cantuche JM: Environmental impacts of changes to healthier diets in Europe. Ecological Economics 2011, 70:1776-1788.

54. Popp A, Lotze-Campen H, Bodirsky B: Food consumption, diet shifts and associated non-CO2 greenhouse gases from agricultural production. Global Environmental Change 2010, 20:451-462.

55. Angelsen A: Policies for reduced deforestation and their impact on agricultural production. Proceedings of the National Academy of Sciences of the United States of America 2010, 107:19639-19644.

56. Searchinger T, Heimlich R, Houghton RA, Dong F, Elobeid A, Fabiosa J, Tokgoz S, Hayes D, Yu T-H: Use of U.S. croplands for biofuels increases greenhouse gases through emissions from land-use change. Science 2008, 319:1238-1240.

57. Danielsen F, Beukema H, Burgess ND, Parish F, Bruhl CA, Donald F, Murdiyarso D, Phalan B, Reijnders L, Struebig M, et al.: Biofuel plantations on forested lands:

Double jeopardy for biodiversity and climate. Conservation Biology 2009, 23:348358.

58. Hall D, Hirsch P, Li TM: Powers of Exclusion. Land Dilemas in Southeast Asia. Singapore: National University of Singapore Press; 2011.

**Landmark book on land governance in Southeast Asia with emphasis on its exclusionary tendencies and theoretical implications for other regions.

59. McCarthy JF: Processes of inclusion and adverse incorporation: oil palm and agrarian change in Sumatra, Indonesia. The Journal of Peasant Studies 2010, 37:821-850.

60. Sikor T, Stahl J, Dorondel S: Negotiating Post-Socialist Property and State: Struggles over Forests in Albania and Romania. Development and Change 2009, 40:171-193.

61. Sikor T, To Xuan Phuc: Illegal Logging in Vietnam: Lam Tac (Forest Hijackers) in Practice and Talk. Society and Natural Resources 2011, 24:688-701.

62. Vandergeest P: Certification and communities: Alternatives for regulating the environmental and social impacts of shrimp farming. World Development 2007, 35:1152-1171.

63. Fuchs D, Kalfagianni A, Arentsen M: Retail power, private standards, and sustainability in the global food system. In Corporate Power in Global Agrifood Governance. Edited by Clapp J, Fuchs D: MIT Press; 2009.

64. Benjaminsen TA, Bryceson I: Conservation, green/blue grabbing and accumulation by dispossession in Tanzania. Journal of Peasant Studies 2012, 39:335-355.

65. Gilberthorpe E: Fasu solidarity: A Case Study of Kin Networks, Land Tenure and Oil Extraction in Kutubu, Papua New Guinea. American Anthropologist 2007, 109:101-112.

66. Klooster D: Environmental Certification of Forests in Mexico: The political ecology of a nongovernmental market intervention. Geoforum 2010, 41:117-129.

67. Mattli W, Buethe T: Setting international standards - technological rationality or primacy of power? World Politics 2003, 56:1-42.

68. Yan H, Sautman B: Chinese Farms in Zambia: From Socialist to “Agro-Imperialist” Engagement? African and Asian Studies 2010, 9:307-333.

69. Eckersley R: The big chill: WTO and multilateral environmental agreements. Global Environmental Politics 2004, 4:24-50.

70. Bush R: Food riots: Poverty, power and protest. Journal of Agrarian Change 2010, 10:119-129. 
71. Hall J, Matos S, Severino L, Beltrao N: Brazilian biofuels and social exclusion: established and concentrated ethanol versus emerging and dispersed biodiesel. Journal of Cleaner Production 2009, 17:S77-S85.

72. Kent G: Global Obligations for the Right to Food. Plymouth, UK: Rowman and Littlefield Publishers; 2008.

73. Gentry B, Sikor T, Auld G, Bebbington AJ, Benjaminsen TA, Hunsberger C, Izac A-M, Margulis ME, Plieninger T, Schroeder $\mathrm{H}$, et al.: Changes in Land Governance in an Urban Era. In Rethinking Global Land Use in an Urban Era. Edited by Seto K, Reenberg A: MIT Press; 2014. 